\title{
Demographic characteristics, nutritional status, dietary and physical activity habits, Helicobacter pylori infection, and intestinal parasitosis among children at municipal preschools in Cuenca, Ecuador
}

\author{
Matthew L. Romo ${ }^{1}$ (D), Adriana Orellana-Paucar ${ }^{2,3}$ (D), Lourdes Huiracocha ${ }^{2,3}$ (D), Victoria Abril- \\ Ulloa $^{2,3 *}$ (iD \\ ${ }^{1}$ Department of Epidemiology \& Biostatistics, CUNY Graduate School of Public Health and Health \\ Policy, City University of New York, United States of America. \\ ${ }^{2}$ Facultad de Ciencias Médicas, Universidad de Cuenca, Cuenca, Ecuador. \\ ${ }^{3}$ Dirección de Investigación, Universidad de Cuenca, Cuenca, Ecuador. \\ * Autor para correspondencia: Dra. Victoria Abril-Ulloa, victoria.abril@ucuenca.edu.ec
}

Fecha de recepción: 25 de enero 2018 - Fecha de aceptación: 8 de marzo 2018

\begin{abstract}
Ecuador is a country in nutritional transition. National data show that the prevalence of overweight and obesity more than triples from the preschool to school-aged years, while stunting remains prevalent. A cross-sectional study in the municipal preschools in Cuenca was conducted to better understand the contributing factors to this nutritional transition. Of the 97 children in the sample population, $5.3 \%$ were overweight or obese and $8.5 \%$ were stunted. Despite no underweight children, $19.0 \%$ of the parents or caregivers considered their child to be underweight. Most households had some degree of food insecurity (71.4\%). Parents reported that most children drank water daily at home (70.5\%), but according to the teachers, less than half drank water at school daily (41.5\%). Parents and teachers, respectively, reported that $89.5 \%$ and $34.7 \%$ of the children consumed vegetables daily and $70.5 \%$ and $57.9 \%$ consumed fruit daily at home or school. About three-quarters of the parents and teachers reported that children dedicated $\geq 1$ hour daily to physical activity, at home and school. Half of the parents reported that their child spent at least 2 hours per day watching the television, using an electronic tablet or computer. Stool examination showed that $26.1 \%$ of children were positive for Helicobacter pylori antigen and $19.3 \%$ for intestinal parasites. This study provided insight into potential areas to focus health education and promotion among this population, for example, in diet and physical activity habits. However, other important factors including poverty related risk factors, such as household food insecurity, and high prevalence of Helicobacter pylori infection and intestinal parasitosis, should be considered simultaneously in such efforts.
\end{abstract}

Keywords: Preschool children, Ecuador, child nutritional sciences, nutrition, sedentary lifestyle, exercise.

\section{RESUMEN}

Ecuador es un país en transición nutricional. Datos nacionales indican que la prevalencia de sobrepeso/obesidad se triplica desde la edad preescolar a la edad escolar, mientras que el retraso del crecimiento sigue siendo prevalente. Se realizó un estudio transversal en centros infantiles municipales en Cuenca, Ecuador, para identificar factores que contribuyen a la transición nutricional. De los 97 niños participantes, $5.3 \%$ tenían sobrepeso/obesidad y el $8.5 \%$ tenían retraso del crecimiento. A pesar de que no hubo casos de niños con bajo peso, el $19.0 \%$ de los padres/cuidadores consideraba que su hijo tenía bajo peso. La mayoría de las familias tenían algún grado de inseguridad alimentaria (71.4\%). Los padres informaron que la mayoría de los niños bebía agua, con una frecuencia diaria, en el hogar (70.5\%), mientras que los profesores señalaron que menos de la mitad consume agua en el centro infantil $(41.5 \%)$. Los padres y profesores informaron que el $89.5 \%$ y el $34.7 \%$ de los niños consumían verduras 
diariamente, y el $70.5 \%$ y el $57.9 \%$ consumían fruta diariamente en casa y en la escuela, respectivamente. Alrededor de $75 \%$ de los padres/cuidadores y profesores informaron que los niños dedicaban $\geq 1$ hora diaria de actividad física en la casa y en el centro infantil. La mitad de los padres informaron que los niños pasaban por lo menos 2 horas diarias frente a la televisión, tableta o computador. En el examen de heces se encontró que el $26.1 \%$ resultó positivo para el antígeno de Helicobacter pylori y el $19.3 \%$ para parásitos intestinales. Este estudio proporciona información sobre áreas potenciales para promover salud y educación en esta población, como por ejemplo hábitos de alimentación y actividad física. Sin embargo, se deberían considerar factores de riesgo relacionados con la pobreza que afectan la salud, como la inseguridad alimentaria y una alta prevalencia de infección por Helicobacter pylori y parasitosis intestinal.

Palabras clave: Preescolares, Ecuador, ciencias de nutrición infantil, nutrición, estilos sedentarios, ejercicio.

\section{INTRODUCTION}

Ecuador is in a nutritional transition where overweight and obesity co-exist with undernutrition. This phenomenon is particularly apparent among children in the country. According to the 2012 Ecuadorian Health and Nutrition Survey (Freire et al., 2014), the prevalence of overweight/obesity among children 0 to 5 years of age was $8.6 \%$ and the prevalence of stunting among this age group 25.3\%. Among 5- to 11-year-old school children, the prevalence of overweight/obesity more than tripled to $29.9 \%$, whereas prevalence of stunting reduced, but remained prevalent at $15.0 \%$. The substantial change in nutritional status from early childhood to middle school age suggests that timely intervention might help reduce overweight and obesity among Ecuadorian children, considering simultaneously the high prevalence of undernutrition.

A number of experimental studies tested educational and behavioral interventions to prevent overweight and obesity among children (Waters et al., 2011; Wang et al., 2015). Some of these studies evaluated intervention programs aiming to improve nutritional and physical activity habits, either at individual or group level, in a variety of settings (e.g., school, home, and/or community), of children of different age (i.e., preschoolers through adolescents). Most of these studies assessed the effect of educational programs on a variety of outcomes, such as the knowledge, attitude and practice of individuals with respect to nutrition and physical activity in relation to the body mass index (BMI) and adiposity. Whereas most of these studies have been conducted in high-income countries in North America and Western Europe, some analyzed the issue in other regions, including Latin America (Verstraeten et al., 2012).

Given the existence of differences in environmental, cultural, and socioeconomic realities between countries, interventions to be effective need most probably be tailored to the socioeconomic and cultural features of the people. Published studies that evaluated intervention programs to improve the nutrition and physical activity habits of preschool children in Ecuador does not exist, although one published study examined the effect of increasing physical activity and reducing screen time among adolescents (Andrade et al., 2014; Andrade et al., 2015). Screening of intervention studies in Latin America on preschoolers in a school-based setting, such as the most recent ones from Colombia (Céspedes et al., 2013a; Céspedes et al., 2013b) and Chile (Vio, Salinas, Montenegro, Gónzales, \& Lera, 2014; Salazar et al., 2014; Kain et al., 2012; Vásquez, Andrade, Rodríguez, \& Salazar, 2008), revealed that uncertainty exists if the applied and analyzed intervention programs are applicable to Ecuadorian preschoolers given the socio-cultural differences even within Latin America. Goals these studies included encompassed improving knowledge and attitudes of healthy eating and being physically active (Céspedes et al., 2013a; Céspedes et al., 2013b), whereas other studies sought to change the nutritional status and body composition in addition to improving physical activity and food/beverage intake (Vio et al., 2014; Salazar et al., 2014; Kain et al., 2012; Vásquez et al., 2008).

Although these studies targeted primarily on the behavior of parents in the interventions, they did not report if household factors, such as the socioeconomic status and food insecurity, were taken into consideration. Furthermore, those studies did not consider the effect of poverty-related risk factors such 
as intestinal parasitosis or Helicobacter pylori infection, both prevalent in Ecuador (Egorov et al., 2010; Jacobsen, Ribeiro, Quist, \& Rydbeck, 2007) and negatively affecting growth and development (Dror \& Muhsen, 2016; Orden et al., 2014; Papier et al., 2014; Phathammavong, Moazzam, Xaysomphoo, Phengsavanh, \& Kuroiwa, 2007). With regard herewith, this study aimed to describe the demographic characteristics, nutritional status, diet and physical activity habits, Helicobacter pylori infection, and intestinal parasitosis among children at municipal preschools in Cuenca (Ecuador), as to better understand the areas intervention programs should address.

\section{MATERIALS AND METHODS}

\subsection{Study procedures}

The research consisted of a cross-sectional study conducted at the end of the school year 2015 in May in 9 municipal preschools in the city of Cuenca. All 3- to 4-year children were included if they were going to the preschool class next school year, starting in September. The children entering the preschool class in September but who did not turn the age of 3 years were excluded. The study consisted of a survey answered by each child's parent or caregiver and teacher, and the measurements and proportions of the child's body, both carried out in school. The research was approved by the institutional review board of the Universidad San Francisco de Quito (2015-52E), and signed informed consent were obtained from all parents or caregivers.

\subsection{Measures}

The parent or caregiver survey included demographic information (e.g., child's sex and age, family composition), questions to assess the socioeconomic status, household food security, child's nutrition and physical activity habits. Some questions were adapted from the core questionnaire of the ToyBox study (parental/caregiver perception of child's weight and child's nutrition/physical activity habits) (Manios et al., 2014; Mouratidou et al., 2014; González-Gil et al., 2014), but with modifications after consultation with school authorities to facilitate the use of the different sections in the questionnaire. The socioeconomic status was determined using the socioeconomic status stratification questionnaire from the Instituto Nacional de Estadística y Censos (INEC) in Ecuador (Instituto Nacional de Estadística y Censos, n.d.). This points-based questionnaire contained 25 questions asking about the family's physical dwelling, access to technology, possession of material goods, consumption habits, education level, and economic activity. The sum of the points on the questionnaires were classified into five socioeconomic levels (high, middle-high, middle, middle-low, and low), as recommended by INEC. Household food security was evaluated using the Latin American and Caribbean Food Security Scale (Food and Agriculture Organization of the United Nations, 2012), consisting of 15 yes/no questions pertaining to household hunger and access to food. With an affirmative answer to each question worth 1 point; a score of 0 was defined as food secure, a score of 1 to 5 defined as mild food insecurity, a score of 6 to 10 interpreted as moderate food insecurity, and a score of 11 to 15 characterized as severe food insecurity. Furthermore, the parents and teachers were asked about the child's typical diet and physical activity habits without any specific recall period. For the nutrition component, questions addressed the weekly frequency (i.e., never, less than once a week, 1-3 days per week, 4-6 days per week, and every day) of water, fruit and vegetable consumption, providing examples for both the last two groups. The physical activity component of the questionnaire asked about daily hours $(<1,1,2,3,4, \geq 5)$ of physical activity (at home, park, or other open area), daily hours of screen time (e.g., watching television or playing with the computer, cellular phone, or tablet) during an average weekday (for both parents and teachers) and weekend (for parents or caregivers only).

Body weight and height were measured to assess the children's nutritional status, using respectively a digital scale (Health o Meter®) calibrated to the nearest $0.1 \mathrm{~kg}$ with the children wearing light clothing, and a portable stadiometer $\left(\mathrm{Seca}{ }^{\circledR}\right)$ with a precision of $1 \mathrm{~mm}$ and with the participants not wearing shoes. Both parameters were measured twice and the average of the two values was used for further analysis. The nutritional status was defined using the 2006 World Health Organization (WHO) growth reference curves for children aged 0 to 60 months (WHO Multicentre Growth Reference Study Group, 
n.d.). The weight status was categorized using the BMI-for-age z-score and the following standard deviation (SD) cut-offs: below -2 SD (underweight), between +2 SD and +3 SD (overweight), and above $+3 \mathrm{SD}$ (obese). The height status was categorized using height-for-age z-score using the following cutoffs: below -2 SD (stunted) and between -2 SD and +2 SD (normal).

For the determination of Helicobacter pylori infection and intestinal parasitosis, stool samples were collected by providing sterile collection containers to parents, informing them about the appropriate collection method of the first stool in the morning. Once the stool samples were collected, they were stored in polystyrene boxes with refrigerant packs to preserve sample integrity before transfer to the laboratory. Determination of $H$. pylori fecal antigen was done using an immunochromatographic technique with the OneStep H. pylori Antigen Rapid Test. The stool specimens were examined by microscope for the presence of parasites using direct wet mount with a native-Lugol (saline and Lugol's iodine solution) preparation. An internal and an external control were done, using 10 randomly selected stool samples and analyzing for $H$. pylori antigens and intestinal parasites by 2 different technicians within the same laboratory and with an external laboratory, obtaining a match of $98 \%$ in the reported results.

\section{3. $\quad$ Statistical analysis}

Records were processed using SAS 9.4 (SAS Institute, Cary NC), and the SAS Macro from WHO (World Health Organization, n.d.) was applied to define the children's nutritional status.

\section{RESULTS}

\subsection{Sample characteristics}

Overall, 105 children were screened from 9 municipal preschools in the city of Cuenca. Of these children, 8 were excluded from the study as 1 parent/caregiver did not want their child to participate, the signed informed consent was not provided by 5 parents, and 3 children did not meet age requirements. Among the 97 children included in the study, there were approximately 11 from each of the 9 centers. The average age was 3.3 years and there were about equal numbers of males and females (Table 1). About one-third of children (31.6\%) lived in a household with a single parent, $45.3 \%$ lived in a household with extended family (e.g., grandparents, aunts, uncles), and $33.4 \%$ were only children. Most of the children (88.6\%) came from middle socioeconomic status households. Food insecurity was prevalent with $71.4 \%$ of households experiencing some degree of food insecurity.

\subsection{Nutritional status and habits}

As outlined in Table 1, none of the children were underweight and relatively few children were overweight/obese $(5.3 \%)$. Stunting affected $8.5 \%$ of children. Even though the children were not underweight, $19.0 \%$ of parents were concerned that their children's weight was low. According to the parents and teachers drink the surveyed children daily water at home (70.5\%) but not at school (41.5\%) (Table 2). Approximately one-third of the children (34.7\%) consume daily vegetables and fruit (70.5\%) at home, however, a larger percentage of children seem to eat vegetables $(89.5 \%)$ and fruits $(57.9 \%)$ at school.

About three-quarters of the parents (72.6\%) and teachers (76.8\%) reported that their children daily spent at least 1 hour of physical activity (Table 2). As shown physical activity increased in the weekends with $95.8 \%$ of children having at least one hour of physical activity. With respect to screen time, as reported by the parents $40.0 \%$ of children spent daily 2 to more hours before a screen at home and in school; which is in contrast by the reporting of the teachers who stated that all children daily had less than 2 hours of screen time. The proportion of children with a screen time of 2 or more hours per day increased to $53.7 \%$ over the weekend. 
Table 1. Demographic characteristics, nutritional status, food insecurity, and perceptions about children's weight.

\begin{tabular}{rc}
\hline & \\
\hline \multicolumn{1}{l}{ Variable } \\
\hline Age in years, mean (SD) (N=97) & $3.3(0.4)$ \\
\hline Gender, n (\%) & $(\mathrm{N}=97)$ \\
Male & $49(50.5 \%)$ \\
Female & $48(49.5 \%)$ \\
\hline Family characteristics, n (\%) & $(\mathrm{N}=95)$ \\
One parent household & $30(31,6 \%)$ \\
Extended family household & $43(45.3 \%)$ \\
Child without parents & $32(33.4 \%)$ \\
\hline Socioeconomic status, n (\%) & $(\mathrm{N}=97)$ \\
Low & $9(9.3 \%)$ \\
Middle-low & $25(25.8 \%)$ \\
Middle & $42(43.3 \%)$ \\
Middle-high & $19(19.6 \%)$ \\
High & $2(2.1 \%)$ \\
\hline Household food security, n (\%) & $(\mathrm{N} 91)$ \\
None & $26(28.6 \%)$ \\
Mild & $47(51.7 \%)$ \\
Moderate & $14(15.4 \%)$ \\
Severe & $4(4.4 \%)$ \\
\hline
\end{tabular}

\begin{tabular}{lc}
\hline Variable & \\
\hline Nutritional status, n (\%) & $(\mathrm{N}=94)$ \\
Underweight & $0(0 \%)$ \\
Normal & $89(94.7 \%)$ \\
Overweight & $4(4.2 \%)$ \\
Obese & $1(1.1 \%)$ \\
\hline Stunting, n (\%) & $(\mathrm{N}=94)$ \\
Yes & $8(8.5 \%)$ \\
No & $86(91.5 \%)$ \\
\hline Parent/caregiver perception of child's weight \\
\multicolumn{3}{c}{$(\mathrm{N}=95)$} \\
Very underweight & $3(3.2 \%)$ \\
Underweight & $15(15.8 \%)$ \\
Normal & $73(76.8 \%)$ \\
Overweight & $2(2.1 \%)$ \\
Very overweight & $2(2.1 \%)$ \\
\hline
\end{tabular}

Table 2. Parent and teacher reported nutrition and physical activity habits at home and school.

\begin{tabular}{|c|c|c|}
\hline Variable & At home & At school \\
\hline Weekly frequency of water consumption, n (\%) & $(\mathrm{N}=95)$ & $(\mathrm{N}=94)$ \\
\hline Never & $3(3.2 \%)$ & $1.0(1.1 \%)$ \\
\hline Less than once a week & $4(4.2 \%)$ & $12(12.8 \%)$ \\
\hline 1-3 days per week & $10(10.5 \%)$ & $34(36.2 \%)$ \\
\hline 4-6 days per week & $11(11.6 \%)$ & $8(8.5 \%)$ \\
\hline Everyday & $67(70.5 \%)$ & $39(41.5 \%)$ \\
\hline Weekly frequency of vegetable consumption, $\mathrm{n}(\%)$ & $(\mathrm{N}=95)$ & $(\mathrm{N}=95)$ \\
\hline Never & $1(1.1 \%)$ & $0(0.0 \%)$ \\
\hline Less than once a week & $4(4.2 \%)$ & $10(10.5 \%)$ \\
\hline 1-3 days per week & $35(36.8 \%)$ & $0(0.0 \%)$ \\
\hline 4-6 days per week & $22(23.2 \%)$ & $0(0.0 \%)$ \\
\hline Everyday & $33(34.7 \%)$ & $85(89.5 \%)$ \\
\hline Weekly frequency of fruit consumption, $\mathrm{n}(\%)$ & $(\mathrm{N}=95)$ & $(\mathrm{N}=95)$ \\
\hline Never & $0(0.0 \%)$ & $0(0.0 \%)$ \\
\hline Less than once a week & $1(1.1 \%)$ & $3(3.2 \%)$ \\
\hline 1-3 days per week & $15(15.8 \%)$ & $35(36.8 \%)$ \\
\hline 4-6 days per week & $12(12.6 \%)$ & $2(2.1 \%)$ \\
\hline Everyday & $67(70.5 \%)$ & $55(57.9 \%)$ \\
\hline Daily hours of physical activity, n (\%) & $(\mathrm{N}=95)$ & $(\mathrm{N}=95)$ \\
\hline \multicolumn{3}{|l|}{ Weekday } \\
\hline$\geq 1$ hour & $69(72.6 \%)$ & $73(76.8 \%)$ \\
\hline$<1$ hour & $26(27.4 \%)$ & $21(22.1 \%)$ \\
\hline \multicolumn{3}{|l|}{ Weekend } \\
\hline$\geq 1$ hour & $91(95.8 \%)$ & NA \\
\hline$<1$ hour & $4(4.2 \%)$ & NA \\
\hline
\end{tabular}


Table 2. (continued)

\begin{tabular}{|c|c|c|c|}
\hline & At home & At school \\
\hline \multirow{7}{*}{ Daily hours of screen time, $\mathrm{n}(\%)$} & & $(\mathrm{N}=95)$ & $(\mathrm{N}=95)$ \\
\hline & Weekday & & \\
\hline & $\geq 2$ hour & $38(40.0 \%)$ & $0(0.0 \%)$ \\
\hline & $<2$ hour & $57(60.0 \%)$ & $95(100.0 \%)$ \\
\hline & Weekend & & \\
\hline & $\geq 2$ hour & $51(53.7 \%)$ & NA \\
\hline & $<2$ hour & $44(46.3 \%)$ & NA \\
\hline
\end{tabular}

\subsection{Stool examination}

Stool samples were obtained from 88 children and were analyzed for the presence of $H$. pylori antigen and intestinal parasites (Table 3). Overall, $26.1 \%$ of children tested positive for $\mathrm{H}$. pylori antigen and 19.3\% for intestinal parasites. The most common parasite detected was Entamoeba histolytica. Among the children who had intestinal parasitosis $58.8 \%$ (10/17) were also positive for $H$. pylori antigen.

Table 3. Helicobacter pylori infection and intestinal parasitosis.

\begin{tabular}{|c|c|}
\hline \multicolumn{2}{|l|}{ Bacteria and parasite infection } \\
\hline H. pylori antigen & $\mathrm{N}=88$ \\
\hline Positive & $23(26.1 \%)$ \\
\hline Negative & $65(73.9 \%)$ \\
\hline Intestinal parasitosis & $\mathrm{N}=88$ \\
\hline Positive & $17(19.3 \%)$ \\
\hline Negative & $71(80.7 \%)$ \\
\hline Specific parasites identified & $\mathrm{N}=17$ \\
\hline Enteromona hominis & $2(11.8 \%)$ \\
\hline Entamoeba histolytica & $10(58.8 \%)$ \\
\hline Entamoeba coli & $2(11.8 \%)$ \\
\hline Giardia lamblia & $2(11.8 \%)$ \\
\hline Giardia lamblia + Entamoeba histolytica & $1(5.9 \%)$ \\
\hline $\begin{array}{l}\text { Positive for } H \text {. pylori antigen (among those } \\
\text { with intestinal parasitosis) }\end{array}$ & $\mathrm{N}=17$ \\
\hline Yes & $10(58.8 \%)$ \\
\hline No & $7(41.2 \%)$ \\
\hline
\end{tabular}

\section{DISCUSSION}

The survey revealed that the children who attend municipal preschools in Cuenca (Ecuador) represent a diverse population, especially in terms of family structure (e.g., a high proportion of single parent households), socioeconomic status, and household food insecurity. Although we did not observe a high prevalence of overweight or obesity, stunting, intestinal parasitosis, and Helicobacter pylori infection were unacceptably prevalent. We identified several important areas to focus interventions aiming to promote the health of the preschool children. Specifically, an intervention could focus on improving daily water, fruit and vegetable consumption at school and home, increasing physical activity and reducing screen time at home. This insight is shared by other studies, such as the ToyBox study in Europe (Summerbell et al., 2012), but the obtained findings provide us with our own context-specific justification. Increasing fruit and vegetable consumption will not be that a problem in Ecuador as both products are inexpensive and amply available, in contradiction to North America and Europe where a socioeconomic gradient for fruit and vegetable consumption exists (Ball et al., 2015). 
Most households in our study had some degree of food insecurity. This is important to consider when including parents in interventions targeting the preschool population. For example, education directed towards parents might include information on economical ways to prepare more abundant and nutritious meals and snacks incorporating local fruits and vegetables. The association between household food insecurity and overweight/obesity in children is unclear and causality is controversial (Gubert, Spaniol, Bortoline, \& Pérez-Escamilla, 2016; Kaur, Lamb, \& Ogden, 2015); however, at the very least, household food insecurity being a risk factor affecting negatively the health status of children is a modifiable factor (Schmeer \& Piperata, 2017). In terms of parental/caregiver perception of their child's weight, $19 \%$ considered their child to be underweight, despite objective anthropometry in our study showed that no child was in fact underweight. Parental misperception of child weight is a common phenomenon (Lundahl, Kidwell, \& Nelson, 2014) and should also be considered a potential risk factor for childhood overweight/obesity. This is clearly an area to educate parents as they might encourage their children to overeat or unnecessarily consume high calorie density foods and drinks. The prevalence of intestinal parasitosis and $\mathrm{H}$. pylori infection reflects the reality of sanitary conditions in Ecuador where mass administration of antiparasitic drugs remains a standard among the pediatric population. The prevalence estimates were not surprising but provided us with a better picture of the health status of the population of preschool children. Implementing an educational and behavioral program to promote nutrition and physical activity habits also gives us the opportunity to promote proper hygiene, complementary to the intervention goals (e.g., hand washing after using the restroom and before eating; washing fruits and vegetables; drinking water from clean sources).

There are some limitations to consider when interpreting our results. Although we used validated surveys for socioeconomic status and household food insecurity, the questions about the children's nutrition and physical activity habits had not been previously validated in a Cuenca population. Thus, the validity of our data is not clear and is likely influenced by reporting biases (e.g., social desirability). Furthermore, the questions on nutrition habits did not include portion sizes, but this was done to make the survey as simple as possible. Despite the limitations, the survey data gave a general idea about specific areas for intervention, which was the goal of this study. We also did not conduct any hypothesistesting statistical tests to determine the association between specific variables or precision around estimates; however, given the small sample size and goals of the study, we deliberately chose to only compute descriptive statistics to provide a general snapshot of the studied population. Finally, the generalizability of our findings is limited to the population in the setting that we studied and may not be applicable to other settings in Ecuador or Latin America. In conclusion, our study provided a better understanding of the characteristics of children in Cuenca's municipal preschools and provided information on the areas to intervene to promote the health of these children. In the near future, we will be designing and carrying out a health promotion intervention in this population focusing on diet and physical activity habits, which has been partly informed by the results of this descriptive study.

\section{ACKNOWLEDGEMENTS}

The authors thank all children and their families, and the teachers and school administrators for making this study possible. We would also like to acknowledge Gabriela Molina and Diana Morales for taking the anthropometric measurements and administering the surveys. The results presented in this paper are part of the project "Impacto de un plan de intervención en hábitos de alimentación, conducta alimentaria y actividad física, en la prevención de exceso de peso en preescolares" (ClinicalTrials.gov identifier: NCT02451410), a project fully funded by the Dirección de Investigación of the Universidad de Cuenca. 


\section{REFERENCES}

Andrade, S., Lachat, C., Ochoa-Avilés, A., Verstraeten, R., Huybregts, L., Roberfroid, D., ... Kolsteren, P. (2014). A school-based intervention improves physical fitness in Ecuadorian adolescents: a cluster-randomized controlled trial. The International Journal of Behavioral Nutrition and Physical Activity, 11, 153. https://doi.org/10.1186/s12966-014-0153-5

Andrade, S., Verloigne, M., Cardon, G., Kolsteren, P., Ochoa-Avilés, A., Verstraeten, R., ... Lachat, C. (2015). School-based intervention on healthy behaviour among Ecuadorian adolescents: effect of a cluster-randomized controlled trial on screen-time. BMC Public Health, 15, 942. https://doi.org/10.1186/s12889-015-2274-4

Ball, K., Lamb, K. E., Costa, C., Cutumisu, N., Ellaway, A., Kamphuis, C. B. M., ... Zenk, S. N. (2015). Neighbourhood socioeconomic disadvantage and fruit and vegetable consumption: a seven countries comparison. The International Journal of Behavioral Nutrition and Physical Activity, 12, 68. https://doi.org/10.1186/s12966-015-0229-x

Céspedes, J., Briceño, G., Farkouh, M. E., Vedanthan, R., Baxter, J., Leal, M., ... Fuster, V. (2013a). Promotion of cardiovascular health in preschool children: 36-month cohort follow-up. The American Journal of Medicine, 126(12), 1122-1126. https://doi.org/10.1016/j.amjmed.2013.06.021

Céspedes, J., Briceño, G., Farkouh, M. E., Vedanthan, R., Baxter, J., Leal, M., ... Fuster, V. (2013b). Targeting preschool children to promote cardiovascular health: cluster randomized trial. The American Journal of Medicine, 126(1), 27-35. https://doi.org/10.1016/j.amjmed.2012.04.045

Dror, G., Muhsen, K. (2016). Helicobacter pylori infection and children's growth: An overview. Journal of Pediatric Gastroenterology and Nutrition, 62(6), e48-59. https://doi.org/10.1097/MPG.0000000000001045

Egorov, A. I., Sempértegui, F., Estrella, B., Egas, J., Naumova, F. N., Griffiths, J. K. (2010). The effect of Helicobacter pylori infection on growth velocity in young children from poor urban communities in Ecuador. International Journal of Infectious Diseases, 14(9), e788-791. doi 10.1016/j.ijid 2010.03.013. Epub 2010 Jul 17

Food and Agriculture Organization of the United Nations. (2012). Latinoamericana y Caribeña de Seguridad Alimentaria (ELCSA). Manual de uso y aplicación. Retrieved from http://www.fao.org/3/a-i3065s.pdf

Freire, W. B., Ramirez Luzuriaga, M. J., Belmont, P., Mendieta, M. J., Silva-Jaramillo, K., Romero, N., ... Monge, R. (2014). Tomo I: Encuesta nacional de salud y nutrición de la población ecuatoriana de cero a 59 años. ENSANUT-ECU 2012 Ministerio de Salud Pública/Instituto Nacional de Estadísticas y Censos (Primera). Quito, Ecuador. Retrieved from http://www.salud.gob.ec/encuesta-nacional-de-salud-y-nutricion-ensanut/

González-Gil, E. M., Mouratidou, T., Cardon, G., Androutsos, O., De Bourdeaudhuij, I., Góźdź, M., ... ToyBox-study group. (2014). Reliability of primary caregivers reports on lifestyle behaviours of European pre-school children: the ToyBox-study. Obesity Reviews: An Official Journal of the International Association for the Study of Obesity, 15(Suppl 3), 61-66. https://doi.org/10.1111/obr.12184

Gubert, M. B., Spaniol, A. M., Bortolini, G. A., Pérez-Escamilla, R. (2016). Household food insecurity, nutritional status and morbidity in Brazilian children. Public Health Nutrition, 19(12), 2240-2245. https://doi.org/10.1017/S1368980016000239

Instituto Nacional de Estadística y Censos. (n.d.). Encuesta de estratificación del nivel socioeconómico. Retrieved 22 January 2018, from http://www.ecuadorencifras.gob.ec/encuestade-estratificacion-del-nivel-socioeconomico/

Jacobsen, K. H., Ribeiro, P. S., Quist, B. K., Rydbeck, B. V. (2007). Prevalence of intestinal parasites in young Quichua children in the highlands of rural Ecuador. Journal of Health, Population, and Nutrition, 25(4), 399-405. 
Kain, J., Leyton, B., Concha, F., Weisstaub, G., Lobos, L., Bustos, N., Vio, F. (2012). Evaluación de una intervención en educación alimentaria y actividad física para prevenir obesidad infantil en escuelas públicas de Santiago de Chile. Archivos Latinoamericanos de Nutrición, 62(1), 60-67.

Kaur, J., Lamb, M. M., Ogden, C. L. (2015). The association between food insecurity and obesity in children - The National Health and Nutrition Examination Survey. Journal of the Academy of Nutrition and Dietetics, 115(5), 751-758. https://doi.org/10.1016/j.jand.2015.01.003

Lundahl, A., Kidwell, K. M., Nelson, T. D. (2014). Parental underestimates of child weight: A metaanalysis. Pediatrics, peds.2013-2690. https://doi.org/10.1542/peds.2013-2690

Manios, Y., Androutsos, O., Katsarou, C., Iotova, V., Socha, P., Geyer, C., ... ToyBox-study group. (2014). Designing and implementing a kindergarten-based, family-involved intervention to prevent obesity in early childhood: the ToyBox-study. Obesity Reviews: An Official Journal of the International Association for the Study of Obesity, 15(Suppl 3), 5-13. https://doi.org/10.1111/obr.12175

Mouratidou, T., Miguel, M. L., Androutsos, O., Manios, Y., De Bourdeaudhuij, I., Cardon, G., ... ToyBox-study group. (2014). Tools, harmonization and standardization procedures of the impact and outcome evaluation indices obtained during a kindergarten-based, family-involved intervention to prevent obesity in early childhood: the ToyBox-study. Obesity Reviews: An Official Journal of the International Association for the Study of Obesity, 15(Suppl 3), 53-60. https://doi.org/10.1111/obr.12183

Orden, A. B., Apezteguía, M. C., Ciarmela, M. L., Molina, N. B., Pezzani, B. C., Rosa, D., Minvielle, M. C. (2014). Nutritional status in parasitized and nonparasitized children from two districts of Buenos Aires, Argentina. American Journal of Human Biology: The Official Journal of the Human Biology Council, 26(1), 73-79. https://doi.org/10.1002/ajhb.22479

Papier, K., Williams, G. M., Luceres-Catubig, R., Ahmed, F., Olveda, R. M., McManus, D. P., ... Ross, A. G. P. (2014). Childhood malnutrition and parasitic helminth interactions. Clinical Infectious Diseases: An Official Publication of the Infectious Diseases Society of America, 59(2), 234-243. https://doi.org/10.1093/cid/ciu211

Phathammavong, O., Moazzam, A., Xaysomphoo, D., Phengsavanh, A., Kuroiwa, C. (2007). Parasitic infestation and nutritional status among schoolchildren in Vientiane, Lao PDR. Journal of Paediatrics and Child Health, 43(10), 689-694. https://doi.org/10.1111/j.14401754.2007.01192.x

Salazar, G., Vasquez, F., Concha, F., Rodriguez, M. D. P., Berlanga, M. D. R., Rojas, J., ... Andrade, M. (2014). Pilot nutrition and physical activity intervention for preschool children attending daycare centres (JUNJI): primary and secondary outcomes. Nutricion Hospitalaria, 29(5), 10041012. https://doi.org/10.3305/nh.2014.29.5.7316

Schmeer, K. K., Piperata, B. A. (2017). Household food insecurity and child health. Maternal \& Child Nutrition, 13(2). https://doi.org/10.1111/mcn.12301

Summerbell, C. D., Moore, H. J., Vögele, C., Kreichauf, S., Wildgruber, A., Manios, Y., ... ToyBoxstudy group. (2012). Evidence-based recommendations for the development of obesity prevention programs targeted at preschool children. Obesity Reviews: An Official Journal of the International Association for the Study of Obesity, 13(Suppl 1), 129-132. https://doi.org/10.1111/j.1467-789X.2011.00940.x

Vásquez, F., Andrade, M., Rodríguez, M., Salazar, G. (2008). Efecto de un programa de educación nutricional en el consumo de energía y macronutrientes de preescolares asistentes a jardines infantiles Junji de la zona oriente de Santiago, Chile. Archivos Latinoamericanos de Nutrición, 58(3), 241-248.

Verstraeten, R., Roberfroid, D., Lachat, C., Leroy, J. L., Holdsworth, M., Maes, L., Kolsteren, P. W. (2012). Effectiveness of preventive school-based obesity interventions in low- and middleincome countries: a systematic review. The American Journal of Clinical Nutrition, 96(2), 415438. https://doi.org/10.3945/ajcn.112.035378 
Vio, F., Salinas, J., Montenegro, E., Gónzales, C. G., Lera, L. (2014). Efecto de una intervención educativa en alimentación saludable en profesores y niños preescolares y escolares de la región de Valparaíso, Chile. Nutricion Hospitalaria, 29(6), 1298-1304.

Wang, Y., Cai, L., Wu, Y., Wilson, R. F., Weston, C., Fawole, O., ... Segal, J. (2015). What childhood obesity prevention programmes work? A systematic review and meta-analysis. Obesity Reviews: An Official Journal of the International Association for the Study of Obesity, 16(7), 547-565. https://doi.org/10.1111/obr.12277

Waters, E., de Silva-Sanigorski, A., Hall, B. J., Brown, T., Campbell, K. J., Gao, Y., ... Summerbell, C. D. (2011). Interventions for preventing obesity in children. The Cochrane Database of Systematic Reviews, (12), CD001871. https://doi.org/10.1002/14651858.CD001871.pub3

WHO Multicentre Growth Reference Study Group. (n.d.). WHO Child Growth Standards: Length/height-for-age, weight-for-age, weight-for-length, weight-for-height and body mass indexfor-age: Methods and development. Geneva, Switzerland: World Health Organization. 312 p.

World Health Organization. (n.d.). WHO Child Growth Standards SAS igrowup package. Retrieved from http://www.who.int/childgrowth/software/readme_sas.pdf?ua=1 